вас відкривати. Якщо ж ви кілька років однаковий, якщо минулий день нічого не додав до вашого багатства, ви можете стати обридлим і навіть ненависним... Серця й уми юнацтва можна завоювати в наші дні тим сплавом моральної краси та інтелектуального багатства, який відкриває перед юнацтвом все нові й нові якості людини (В. Сухомлинський).

Наведені нами види роботи збагачують педагогічний світогляд студентів та розширюють горизонти їхньої обізнаності зі специфічними рисами професії вчителя, що $\epsilon$ важливим аспектом формування іміджевої компетентності майбутнього вчителя початкової школи.

Отже, іміджева компетентність майбутнього вчителя входить до складу професійної компетентності, а іiі формування $є$ важливою ознакою ефективності освітньо-професійної підготовки та передумовою успішного професійного становлення майбутнього вчителя початкової школи.

\title{
Література
}

1. Димитрова Г. Формиране на бъдеща конкурентоспособна личност чрез образователно възпитателния процес / Гинка Димитрова // Образование и възпитание за утре - между традицията и иновациите / Фондация «Човещина» «Авангард Прима», 2015. С. 230-243. 2. Довга Т. Я. Імідж сучасного вчителя : [навч.-метод. посіб.] / Т. Я. Довга. - [2ге вид., перероб. і доп.]. - Кіровоград: ПП «Ексклюзив-Систем», 2015. - 146 с. 3. Дружилов С. А. Профессиональная компетентность и профессионализм педагога: психологический подход / С. А. Дружилов // Научно-публицистический альманах : CO PАО, ИПК, Новокузнецк. - 2005. - Вып. 8. - С. 40-49. 4. Коджаспирова Г. М. Словарь по педагогике / Г. М. Коджаспирова, А. Ю. Коджаспиров. - Москва : ИКЦ «МарТ»; Ростов н/Д : Издательский центр «МарТ», 2005. - 448 с. 5. Митник М. М. Професійна компетентність вчителя як загальна умова педагогічної діяльності / М. М. Митник // Професійні компетенції та компетентності вчителя [матеріали регіонального науково-практичного семінару]. Тернопіль : Вид-во ТНПУ ім. В. Гнатюка, 2006. - С. 37-40. 6. Перелыгина Е. Б. Имидж как феномен интерсубъектного взаимодействия: Содержание и пути развития: дисс. ... доктора психол. наук по спец. : 19.00.05, 19.00.13 «Психология развития, акмеология». - Москва, 2003. - 697 с. 7. Яндарова С. В. Имидж личности: содержание, функции и мотивации построения: дисс. ... канд. психол. наук по спец.: 19.00.01 «Общая психология, психология личности, история психологии». - Москва, 2005. - 187 с.

УДК 378.14:37.011.31

Наталия Есина

\section{КОМПЕТЕНТНОСТНЫЙ ПОДХОД В ПРОФЕССИОНАЛЬНОЙ ПОДГОТОВКЕ БУДУЩЕГО ПЕДАГОГА}

Єсіна Н. А. Компетентнісний підхід до професійної підготовки майбутнього педагога.

У статті розкрито поняття «компетентність», «професійна компетентність»; описано види і підвиди професійної компетентності майбутнього педагога, які впливають на результати навчально-виховної та управлінської діяльності студентів; подано авторське визначення «компетенція», визначено структурні складники професійної підготовки майбутнього педагога.

Ключові слова: компетентність, компетенція, професійна компетенція, компетентнісний підхід, підготовка майбутнього педагога, професійна підготовка майбутніх педагогів. 
Есина Н. А. Компетентностный подход в профессиональной подготовке будущего педагога.

В статье раскрыто понятие «компетентность», «профессиональная компетентность», «компетентностный подход»; описаны виды и подвиды профессиональной компетентности будущего педагога, которые влияют на результаты учебно-воспитательной и управленческой деятельности студентов; дано авторское определение понятию «компетенция»; определены структурные компоненты профессиональной подготовки будущего педагога.

Ключевые слова: компетентность, компетенция, профессиональная компетенция, компетентностный поход, подготовка будущего педагога, профессиональная подготовка будущого педагога.

Yesina N. A Competence-based approach in the professional training of future teachers.

In the article the concept «competence», «professional competence», «competence-based approach» is shown, types and subspecies of professional competence of future teacher which influence the results of educational and administrative activity of students are described, the author's definition of the concept «competence» is given, structural components of professional training of future teacher are defined.

Key words: competency, competence, professional competence, competence-based approach, teacher's training, teacher's professional training.

Одно из основных требований к выпускнику высшего педагогического заведения быть всесторонне развитым специалистом. Образование все больше ориентируется на высокую культуру, творческую инициативу, самостоятельность, мобильность будущих педагогов, что требует качественно нового подхода к формированию будущего специалиста. Выпускнику педагогического университета придется работать в учебных заведениях разной направленности. В одних случаях для работодателя будет важна квалификация и усвоенные учебные программы, а в других - способность работника, в оптимальный срок реализовать определенный проект, направленный на решение проблем развития организации, предприятия, учреждения.

В последние годы в системе высшего педагогического образования компетентностный подход исследовали много отечественных и зарубежных ученых (Н. Брижак, Н. Ефремова, Н. Нагорная, С. Огарев, О. Пометун, В. Химинец).

Цель статьи - определить роль компетентностного подхода в профессиональной подготовке будущих педагогов.

В настоящее время качество решения задач подготовки специалистов в высших учебных заведениях, как никогда раньше, определяется уровнем компетентности выпускника. Это объясняет использование компетентностного подхода в ходе решения проблемы профессиональной подготовки педагога.

В настоящее время отмечается тенденция введения компетентностного подхода не только в нормативную, но и в практическую составляющую профессиональной подготовки педагога, обосновывается и уточняется номенклатурный перечень, разрабатывается описание содержательных характеристик результирующих единиц содержания профессиональной подготовки педагога (компетентности, компетенции, ключевые квалификации).

О. Пометун рассматривает компетентность как набор знаний, умений, навыков, возможностей и отношений, которые позволяют будущему специалисту определить и 
решить независимо от контекста проблемы, что характерно для определенного направления профессиональной деятельности.

Компетентная личность использует компетентности, которые являются благоприятными для решения определенных задач. Самый низкий уровень компетентности является уровнем деятельности, необходимым и достаточным для минимальной успешности в достижении результата [8, с. 19].

Ю. Тартур считает, что компетентность - это способность личности к осуществлению какой-либо деятельности, каких-либо действий, а компетенция - это содержание компетентности, то есть знания, умения, опыт, которые должны быть усвоены обучающимися для формирования способности и готовности выполнять соответствующую деятельность [10, с. 24].

Под компетентностью педагога В. Химинец понимает специально структурированные наборы знаний, умений, навыков, которые приобретаются в процессе обучения. Общие и профессиональные компетентности человек использует в разных сферах деятельности для выполнения определенных заданий [11].

Однако в современной педагогической науке нет единого подхода к определению профессиональной компетентности будущего педагога. Существует несколько точек зрения, касающихся определения данного понятия.

Во-первых, компетентность рассматривается как одна из ступеней профессионализма, которая составляет основу педагогической деятельности учителя. Факторами, обуславливающими уровень проявления профессионализма, являются социальная и профессиональная направленность, педагогические способности, культура мышления.

Во-вторых, профессиональная компетентность учителя представлена как способность личности на разном уровне решать различные типы педагогических задач.

В связи с этим существует несколько дефиниций термина «профессиональная компетентность».

Т. Сорокина под. профессиональной компетентностью педагога понимает единство его теоретической и практической готовности к осуществлению своей педагогической деятельности [9, с. 25].

Ю. Тартур считает, что понятие «профессиональная компетентность» представляет собой совокупность способностей, качеств и свойств личности, необходимых для успешной профессиональной деятельности в той или иной сфере [10, с. 25].

Н. Ефремова, придерживаясь синергетического подхода, определяет профессиональные компетенции педагога как «обобщенные и глубоко сформированные качества личности, ее способность наиболее универсально использовать и применять полученные знания и навыки»; «совокупность знаний, умений и навыков, позволяющих субъекту приспособиться к изменяющимся условиям, ... способность действовать и выживать в данных условиях». С позиции личностно-ориентированного обучения, к этому перечню можно добавить совокупность смысловых ориентаций, необходимых для продуктивной деятельности [3, с. 327].

Мы понимаем под профессиональной компетентностью способность будущего учителя выполнять свою профессиональную деятельность, используя приобретенные профессиональные знания, умения и навыки в ходе обучения.

В структуре профессиональной компетенции педагога ученые определяют разные компоненты. Так, Е. Огарев утверждает, что компетентность состоит из пяти основных компонентов: 
- полное понимание сущности заданий и проблем, которые решаются;

- хорошие знания накопленного в определенной отрасли опыта;

- умение выбирать средства и способы действия, адекватное конкретным обстоятельствам места и времени;

- чувство ответственности за достигнутые результаты;

- способность учиться на ошибках и вносить корективы в процесс достижения целей [7, с. 27].

Т. Сорокина выделяет в структуре профессиональной компетентности будущего педагога такие составляющие:

1) мотивационный компонент, выражающийся в постепенном развитии особой направленности учебно-профессиональной деятельности студента, основанной на приоритете целей развития личности младшего школьника;

2) профессионально-деятельностный компонент, содержащий систему учебнопрофессиональных действий, который предполагает овладение студентами:

- специфическими аналитическими навыками, позволяющими воспринимать и оценивать педагогическую ситуацию как многомерную, постоянно инновационную педагогическую реальность;

- особыми профессионально-диагностическими действиями, позволяющими будущему педагогу преобразовывать учебный предметный материал (математический, природоведческий) в диагностический [9, с. 25].

В. Лозовая отмечает, что компетентность имеет интегративную природу, потому что ее источником являются разные сферы культуры (духовная, общественная, социальная, педагогическая, управленческая, правовая етическая, экологическая и другие), она требует большого интеллектуального развития [5]. М. Васильева считает, что логично будет дополнить перечень видов профессиональной компетентности педагога деонтологической компетентностью, которая является одной из необходимых сосотавных частей данного феномена [2]. Л. Карпова выделяет следующие подвиды профессиональной компетентности: методологическую, практическо-деятельностную, дидактико-методическую, коммуникативную, экономико-правовую, управленческую [4, с. 86].

Формирование компетентности в образовательном процессе выдвигает на первое место не информированность обучаемого, а умение разрешать проблемы в различных cферах.

По мнению А. Хуторского, это позволяет решить проблемы, когда студенты могут глубоко овладеть системой теоретических знаний, но сталкиваются с большими трудностями в деятельности, которая требует использования этих знаний для решения конкретных заданий или решения проблемных ситуаций на практике [12, с. 62].

Реализация компетентностного подхода зависит от всей образовательно-культурной ситуации, в которой живет и развивается будущий педагог.

Характеризуя компетентностный подход, В. Химинец подчеркивает, что умеет учиться тот, кто осознает цель педагогической деятельности, мотивированный на педагогическую деятельность, умеет ее организовывать, подбирать нужные знания, которые предусмотрены планом, осуществляет мониторинг и самоконтроль педагогической деятельности и стремится ее усовершенствовать [11].

По мнению Н. Нагорной, компетентностный подход выдвигает на первое место не информированность будущего педагога, а умения решать проблемы, которые возникают в педагогической деятельности. Этот подход не сводиться только к получению 
профессиональных знаний, а предусматривает целостный опыт решения жизненных проблем, выполнения ключевых функций, социальных ролей, компетенций [6, с. 267]. С позиции компетентностного похода, уровень профессиональной подготовки будущих педагогов определяется способностью специалиста решать проблемы разной сложности, опираясь на опыт и знания.

Мы считаем, что в системе компетентностного подхода к профессиональной подготовке будущих педагогов, нужно отдавать преимущество коммуникативноситуативным заданиям и заданиям, которые требуют применения опыта студентов, приближенные к жизни, будущей профессиональной деятельности, стимулируют их мыслительную деятельность.

Мы разделяем точку зрения Н. Брижак, которая считает, что в структуру компетентностного подхода к профессиональной подготовке будущего педагога входят: компетентностный специалист, компетенция и компетенции, профессиональная компетентность, профессиональная деятельность будущего педагога [1, с. 47].

Таким образом, имеет место потребность реформировать современную систему образования в направлении компетентностного подхода. Он отображает представления о профессионализме современного педагога и помогает ему применять свои знания на практике.

\section{Литература}

1. Брижак Н. Компетентнісний підхід у підготовці майбутнього педагога / Н. Брижак // Науковий вісник Ужгородського національного університету. - Ужгород. 2012. - С. 46-48. 2. Васильєва М. П. Теорія педагогічної деонтології / М. П. Васильєва. Харків : Нове слово, 2003. - 216 с. 3. Ефремова Н. Ф. Компетенции в образовании: формирование и оценивание / Н.Ф. Ефремова. - Москва: Национальное образование, 2012. - 416 с. 4. Карпова Л. Г. Складники професіоналізму вчителя / Л. Г. Карпова // Проблеми підготовки викладачів до здійснення сучасної освіти: [зб. наук. пр.] // Проблеми сучасності: культура, мистецтво, педагогіка. - Харків : Стиль Іздат, 2006. - С. 46-53. 5. Лозова В. I. Стратегічні питання сучасної дидактики / В. І. Лозова. - Харків : Шлях освіти. - № 2. - 2003. - С. 11-16. 6. Нагорна Н. В. Формування у студентів понять компетентності й компетенції / Н. В. Нагорна // Виховання і культура. - 2007. - № 1-2 (1112). - С. 266-268. 7. Огарев Е. И. Компетентность образования: социальный аспект [текст] / Е. И. Огарев. - Санкт-Петербург : РАОИОВ, 1995. - 39 с. 8. Пометун О. І. Формування громадянської компетентності: погляд з позиції сучасної педагогічної науки / О. І. Пометун // Вісник програм шкільних обмінів. $-2005 .-$ № 23. - С. 18-20. 9. Сорокина Т. М. Профессиональная компетентность как фактор профессиональной успешности / Т. М. Сорокина // Акмеология. - 2007. - № 1. - С. 23-27. 10. Тартур Ю. Г. Компетентность в структуре модели качества подготовки специалиста / Ю. Г. Тартур // Высшее образование сегодня. - 2004. - № 3. - С. 20-26. 11. Химинець В. Компетентнісний підхід до професійного розвитку вчителя [Електронний ресурс] / В. Химинець.- Режим доступу: http://zakinppo.org.ua/ 2010-01-18-13-44-15/233-2010-08-25-07-10-49 [http:// zakinppo.org. ua/2010-01-18-13-44-15/233-2010-08I 12. Хуторской А. В. Ключевые компетенции как компонент личностно-ориентированной парадигмы образования / А. В. Хуторской // Народное образование. - 2003. - № 2. - С. 58-64. 